\title{
Chronic myeloid leukemia in the Imatinib era - Compilation of Indian data from 22 centers involving 8115 patients
}

In India, chronic myeloid leukaemia (CML) is the most common adult leukemia. ${ }^{[1]} \mathrm{CML}$ is characterized by excessive tyrosine kinase activity resulting from a chimeric BCR-ABL fusion protein and balanced reciprocal translocation $[\mathrm{t}(9 ; 21)]$ typically between chromosome 9 and 21. ${ }^{[2,3]}$ Many of us in India have gone through the era of treating this disease with chemotherapy, interferon, busulfan, hydroxyurea, and allogeneic hematopoietic stem cell transplantation - sharing with our patients, the pain of suboptimal outcome (in terms of efficacy, morbidity, and mortality) as well as limited applicability [cost and availability of human leukocyte antigen (HLA)-matched donor]. ${ }^{[1,4-6]}$

Beginning of the $21^{\text {st }}$ century coincided with a dramatic change in the CML landscape. The unflinching determination of Dr. Brian Druker and Nicholas Lydon to target this genetic abnormality finally led to the discovery of STI571 "Imatinib" which quickly proved to be the "magic bullet" poster boy for the year of targeted therapy and personalized medicine. ${ }^{[7,8]}$

Ten years into the Imatinib era provided us with sufficient opportunity to gather insight into its role and application in the Indian scenario. The Indian Cooperative Oncology Network (ICON) Trust pioneered a platform for key hematologists and medical oncologists from major cancer centers of the country to share their experience and data on CML patients. Dr. Kumar Prabhash was the organizer of this "Indian evidence of CML-Mylestone" as in conference. This meeting coincided with the $50^{\text {th }}$ year celebration of the discovery of Philadelphia Chromosome and was an apt tribute, with presentation of data from 22 centers comprising 8115 patients - the largest collection of data from a single country. This issue of IJMPO is a compilation of manuscripts of these data as well as a synopsis of resultant collaborations.

\begin{tabular}{|l|l|}
\hline \multicolumn{2}{c|}{ Access this article online } \\
\hline Quick Response Code: & Website: \\
\hline & Www.jmpo.org \\
\hline & \\
\hline
\end{tabular}

This compilation of Indian data also gives the unique opportunity to have large-scale comparison of the outcome between innovator Imatinib and its generic biosimilar versions. While targeted therapies are a boon, they were hitherto tagged with a cost burden even for high-income countries. The original Imatinib was beyond the reach of most average Indians, even after taking into consideration patient assistance programs. Under these circumstances, generic Imatinib was used extensively. Their efficacy and toxicity is captured in this issue and will become a valuable reference.

We enjoyed the daunting task of putting together this issue. We congratulate all the contributors and hope that this initiative sets precedence for data collection, presentation, and compilation from all over India. Already India is part of pivotal CML studies where data are submitted globally for regulatory approval..$^{[9]}$ Such opportunities not only allow us to lead in the development of global medical knowledge, but also help us optimize the outcome among Indian patients in the most impactful and cost-effective manner.

\section{Purvish Parikh, Shweta Bansal}

Medical Oncologist and Hematologist, SAARC Federation of Oncology, ${ }^{1}$ Hemato-Oncologist, Ayurvihar Asian Institute of Oncology, K. J. Somaiya Campus, Sion, Mumbai, Maharashtra, India E-mail: purvish1@gmail.com

\section{REFERENCES}

1. Parikh PM, Charak BS, Banavali SD, Koppilar S, Giri NK, Kumar A, et al. Retrospective analysis of 224 cases of CML. Indian J Hematol 1988;6:85-7.

2. Parikh PM, lyer RS, Saikia TK, Gopal R, Advani SH. Philadelphia chromosome. J Assoc Physicians India 1992;40:98-100.

3. Barbhaya SA, Parikh PM, Desai S. Bcr-c.abl detection by southern blotting in CML. Indian J Hematol 1993;11:27.

4. Banavali SD, Parikh PM, Nanjangud G. Results of treatment of CML with a cisplatin based intensive treatment regimen (TMH 8802 protocol). Indian J Hematol 1993;11:244-51.

5. Giles FJ, Hehlmann R, Hockhaus A, Parikh PM. Initial characterization of philadephia chromosome chronic phase CML: A comparison between Asian and German patients on the International Oncology Study Group the German CML study group protocol. Int J Hematol 1996;64:294.

6. Saikia TK, Advani SH, Parikh PM, Bapna A, Somjee S, Mukhopadhyay A, et al. Results of Allogeneic Bone Marrow transplant in Chronic Myeloid Leukemia (CML) following conditioning with Busulfan and cyclophosphamide. J Assoc Physicians India 1999;47:770-3. 
7. Druker BJ, Talpaz M, Resta DJ, Peng B, Buchdunger E, Ford $\mathrm{JM}$, et al. Efficacy and safety of a specific inhibitor of the BCR-ABL tyrosine kinase in chronic myeloid leukemia. $\mathrm{N}$ Engl J Med 2001;344:1031-7.

8. O'Brien SG, Guilhot F, Goldman JM, Hochhaus A, Hughes TP, Radich JP, et al. International Randomized Study of Interferon versus STI571 (IRIS) 7-year follow-up: Sustained survival, low rate of transformation and increased rate of major molecular response (MMR) in patients (pts) with newly diagnosed chronic myeloid leukemia in chronic phase (CMLCP) treated with imatinib (IM). Blood 2008;112:76.
9. Cortes J, Lipton JH, Rea D, Digumarti R, Chuah C, Nanda $\mathrm{N}$, et al. Phase 2 study of subcutaneous omacetaxine mepesuccinate after TKI failure in patients with chronic-phase CML with T315I mutation on behalf of the Omacetaxine 202 Study Group. Blood 2012;120:2573-80.

How to cite this article: Parikh $\mathrm{P}$, Bansal S. Chronic myeloid leukemia in the Imatinib era - Compilation of Indian data from 22 centers involving 8115 patients. Indian J Med Paediatr Oncol 2013;34:145-6.

\section{Android App}

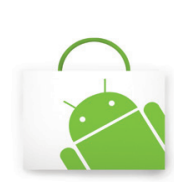

Download

Android application

A free application to browse and search the journal's content is now available for Android based mobiles and devices. The application provides "Table of Contents" of the latest issues, which are stored on the device for future offline browsing. Internet connection is required to access the back issues and search facility. The application is compatible with all the versions of Android. The application can be downloaded from https://market.android.com/details?id=comm.app.medknow. For suggestions and comments do write back to us. 